\title{
THE IMPACT OF THE KOWALSKIE RESERVOIR ON THE HYDROLOGICAL REGIME ALTERATION OF THE GŁÓWNA RIVER
}

\author{
Mariusz Sojka', Joanna Jaskuła', Joanna Wicher-Dysarz², Tomasz Dysarz² \\ 1 Institute of Reclamation, Land Improvement and Geodesy, Faculty of Environmental Engineering and \\ Landscape Planning, Poznan University of Life Sciences, Piątkowska 94, 60-649 Poznań, Poland, e-mail: \\ jaskula@up.poznan.pl \\ 2 Department of Hydraulic and Sanitary Engineering, Faculty of Environmental Engineering and Landscape \\ Planning, Poznan University of Life Sciences, Piątkowska 94 Str., 60-649 Poznań
}

Received: 2016.06.23

Accepted: 2016.08.08

Published: 2016.09.20

\begin{abstract}
This paper present an assessment of the impact of the Kowalskie reservoir on the hydrological regime alteration of the Główna river. The Główna river is a right tributary of the Warta river. The Kowalskie reservoir was built in 1984. The area of the reservoir in the normal condition is 203 ha and total capacity is $6.58 \times 106 \mathrm{~m}^{3}$. The impact of the Kowalskie reservoir on the hydrological regime was made on the basis of RVA method. The assessment was based on the analysis of flow series from the period of 1971-2012. The calculations were done by means of IHA software version 7.1.0.10 developed by The Nature Conservancy (2009). This study indicate that the Kowalskie reservoir has an impact on two group of flow parameters that characterized frequency and duration of high and low pulses as well as rate and frequency of water condition change. The others flow parameters characterized magnitude and duration of annual extreme water conditions are less affected by the Kowalskie reservoir. This study show that Kowalskie reservoir play important role in flood protection. Additionally the reservoir operation has an positive effect on minimum flows characteristic and base flow index.
\end{abstract}

Keywords: lowland river, reservoir, hydrological regime, water stage, discharge.

\section{INTRODUCTION}

The hydrological regime plays a major rule to aquatic ecosystem. Hydrologic conditions determine the composition, structure and function of aquatic, wetland and riparian ecosystem [Richter et al. 1996]. Land-use and land-cover conversion, flow diversion, dam construction and ground water withdrawal alter the hydrologic regime. Dams impacts the entire range of hydrologic characteristics most significantly [Wang et al. 2015]. The strength of the impact depends on seasonal flow variation in the river. This natural process may be modified by reservoir forcing detention or release of water [Guo et al. 2012]. The analysis of annual and monthly flow regime shows a increase in low flow and a decrease in high flow [Tebakari et al. 2012, Matos et al. 2010]. Magilligan and Nislow (2005) indicate that most significant changes oc- curred in minimum and maximum flows over different durations. The dam operation decreases maximum flows, rise and fall rates and flow variability. In the same time the dam causes visible increases of minimum flows [Batalla et al. 2004, Magilligan and Nislow 2005, Yan et al. 2010, Zuo and Liang 2015].

To evaluate the ecological effect of hydrological regime alteration over 170 hydrologic indicators have been used around the World [Olden and Poof 2003]. However, the method based on Indicators of Hydrologic Alteration (IHA) are used mainly [Fantin-Cruz et al. 2015]. Richter et al. (1996) developed the set of indicators for assessment of the dam construction impact on river hydrological regime alteration. The applied indicators described the flow magnitude, timing, frequency, duration and rate of change. They were divided into five groups as follows: group 
1 - magnitude of monthly water conditions, group 2 - magnitude and duration of annual extremes, group 3 - timing of annual extremes, group 4 frequency and duration of high and low pulses and group 5 - rate and frequency of change in conditions. Richter et al. (1997) proposed the Range of Variability Approach (RVA) to assess the hydrological alteration (HA). This method enables to evaluate the degree of alteration by giving a target range for each indicator. In order to improve the interpretation of the RVA approach Richter et al. (1998) developed three-class scale representing low, moderate and high alteration of hydrological regime. The assessment of river hydrologic regime alteration by means of IHA method is conducted on the basis on daily flow series from the period before and after dam construction. The data obtained from the first gauge station located downstream the reservoir are used mainly [Richter et al. 1996, Yu et al. 2015].

The aim of the presented study is to assess the impact of the Kowalskie reservoir on the hydrological regime of the Główna river. The assessment is based on the analysis of flow series from the period of 1971-2012.

\section{MATERIALS AND METHODS}

The Wierzenica gauge station is selected for analyzing the hydrological regime alteration of the Główna River. This gauge station is located in $\mathrm{km} 9+400$ of the river, what is about $6 \mathrm{~km}$ down- stream of the main dam (Figure 1). The drainage area down to Wierzenica gauge station is 222 $\mathrm{km}^{2}$. The hydrological data at the Wierzenica gauge station are available for the years 19582012. The data from the period of 1958 to 1983 are obtained from the Hydrological Annuals of the Oder River. The daily water levels and flows from 1984 to 2012 are provided by the Institute of Meteorology and Water Management - National Research Institute.

The analysis presented in this paper is based on daily flows from 1971 to 2012 . The daily water level data available for the period 19581960 are not used in present study. The reason is the change of the gauge zero and no uniformity of the data. Monthly water stages are only available for the period of 1961-1970. Such data should not be used to assess the hydrological regime alteration by means of RVA method based on daily flow data.

During the hydrological years from 1971 to 1976 only daily water levels were observed (Table 1). Therefore, in the first stage of this study we develop the rating curve which shows the relationship between the water levels and flows. The rating curve is elaborated using Bubenday's and Harlacher's method. The simultaneous flows at different water levels in Wierzenica gauging station from November 1970 to October 1980 are used. The data are obtained from Hydrometric measurements developed by the Institute of Meteorology and Water Management. Afterwards, the rating curve is tested on the basis of daily

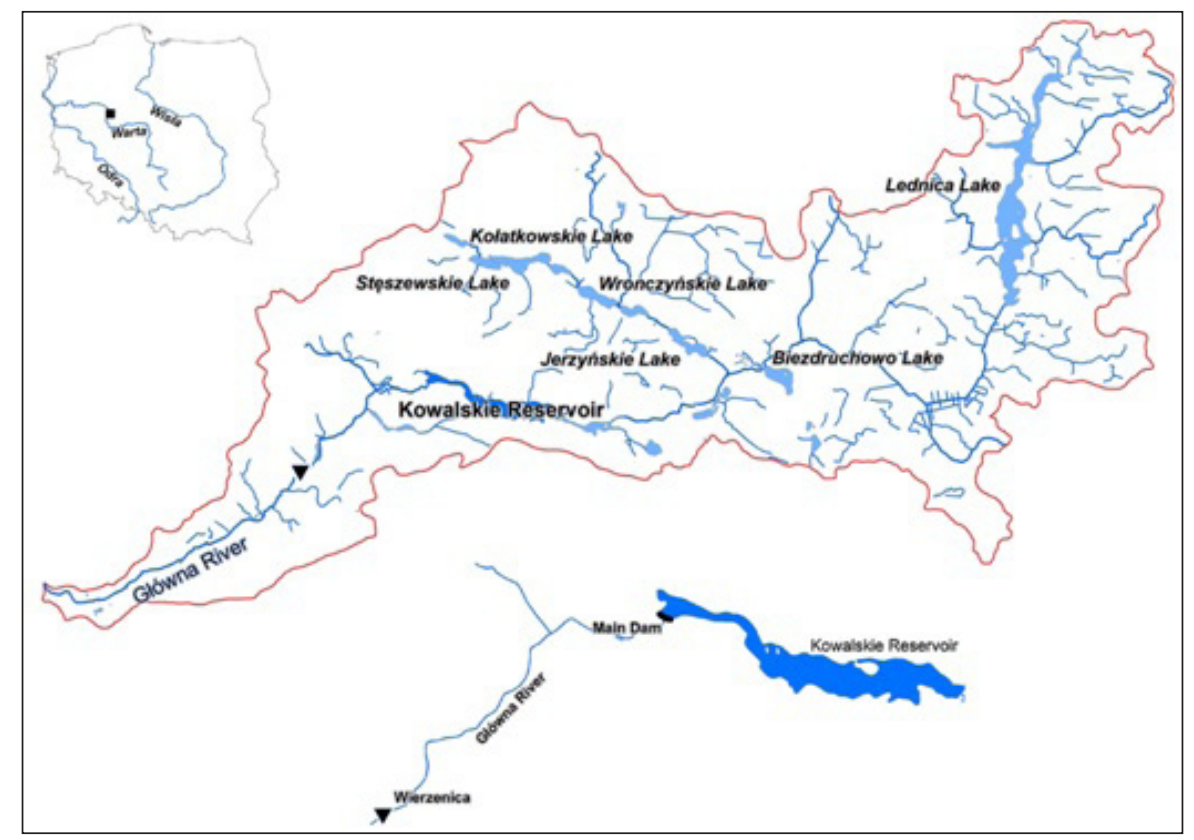

Figure 1. Study site location 
Table 1. Hydrological data availability

\begin{tabular}{|c|c|c|c|c|}
\hline Period & Monthly water levels & Monthly water flows & Daily water levels & Daily water flows \\
\hline $1958-1960$ & & & + & \\
\hline $1961-1970$ & + & & + & \\
\hline $1971-1976$ & & & + & + \\
\hline $1977-1983$ & & & + & + \\
\hline $1984-2012$ & & & + & + \\
\hline
\end{tabular}

water levels and flows available from November 1977 to October 1983. The test is conducted in two steps. In the first step, based on the rating curve equation and water levels, the daily flows are calculated. In the second step the differences between daily flows obtained from Hydrological Annuals of the Oder River and the values calculated in the first step are assessed. Next the flows data were evaluated in terms of statistical homogeneity, using the Kruskal-Wallis test on the significance level of 0,05 [Pociask-Karteczka 2006]. The flow data were divided in two series 1971-1983 and 1984-2012. the analysis showed that the flows are statistically homogeneous and characterized by a negative trend.

In the second stage the RVA methods is used. These methods employs 33 parameters, which are categorized into five groups describing the magnitude, timing, frequency, duration, and rate of change (Table 2). Because zero-flow days were not observed during the study period, the parameter "number of zero-flow days" is not included in the study.

Subsequently, the medians (Med), coefficients of dispersion (CoD), ranges (Min, Max) and degree of HA are computed. The main elements of the RVA method are target ranges, which are defined as the 25 th and 75 th percentile values of a particular parameter. These values are calculated on the basis of available pre-impact data. The hydrologic alteration (HA) shows the degree of RVA target range non-attainment. HA can be calculated as follows

$$
H A=\frac{O F-E F}{E F}
$$

where: $E F$ - means expected frequency, $O F$ - the observed frequency in post-dam period.

Table 2. IHA parameters

\begin{tabular}{|c|c|c|}
\hline IHA statistics & Regime characteristics & Hydrologic parameters \\
\hline Group 1: Magnitude of monthly water conditions & $\begin{array}{l}\text { Magnitude } \\
\text { Timing }\end{array}$ & Mean value for each calendar month \\
\hline $\begin{array}{l}\text { Group 2: Magnitude and duration of annual } \\
\text { extreme water conditions }\end{array}$ & $\begin{array}{l}\text { Magnitude } \\
\text { Duration }\end{array}$ & $\begin{array}{l}\text { Annual minima 1-day means } \\
\text { Annual maxima 1-day means } \\
\text { Annual minima 3-day means } \\
\text { Annual maxima 3-day means } \\
\text { Annual maxima 7-day means } \\
\text { Annual minima 7-day means } \\
\text { Annual maxima 30-day means } \\
\text { Annual maxima 30-day means } \\
\text { Annual minima 90-day means } \\
\text { Annual maxima 90-day means } \\
\text { Number of zero days } \\
\text { Base flow index }\end{array}$ \\
\hline $\begin{array}{l}\text { Group 3: Timing of annual extreme water } \\
\text { conditions }\end{array}$ & Timing & $\begin{array}{l}\text { Julian date of each annual 1-day minimum Julian } \\
\text { date of each annual 1-day maximum }\end{array}$ \\
\hline $\begin{array}{l}\text { Group 4: Frequency and duration of high and } \\
\text { low pulses }\end{array}$ & $\begin{array}{l}\text { Magnitude } \\
\text { Frequency } \\
\text { Duration }\end{array}$ & $\begin{array}{l}\text { No. of low pulses each year } \\
\text { Mean duration of low pulses within each year } \\
\text { No. of high pulses each year } \\
\text { Mean duration of high pulses within each year }\end{array}$ \\
\hline $\begin{array}{l}\text { Group 5: Rate and frequency of water condition } \\
\text { change }\end{array}$ & $\begin{array}{l}\text { Frequency } \\
\text { Rate of change }\end{array}$ & $\begin{array}{l}\text { Rise rate } \\
\text { Fall rate } \\
\text { Number of reversals }\end{array}$ \\
\hline
\end{tabular}


Hydrologic alteration is equal to zero when the observed frequency of post-dam annual values falling within the RVA target range boundaries equals the expected frequency. A positive value indicates that parameter values fell inside the RVA boundaries more often than expected; negative values indicate that values fell within the RVA boundaries less often than expected. The degree of HA are classified into three group: (1) minimal or no alteration $(0-33 \%$ as indicated by L), (2) moderate alteration (34-67\% as indicated by $\mathrm{M}$ ) and (3) high alteration (68-100\% as indicated by $\mathrm{H}$ ). All calculations are done by means of IHA software version 7.1.0.10 developed by The Nature Conservancy (2009).

\section{STUDY SITE DESCRIPTION}

The Kowalskie Reservoir is located on the Główna river which is a right tributary of the Warta river. The basin of the Główna river is located in the central part of Poland. This agricultural region is characterized by low water resources. The average annual rainfall in Główna river basin is 545 $\mathrm{mm}$ and the mean temperature is $8{ }^{\circ} \mathrm{C}$. The total drainage area of the Główna river is $235.81 \mathrm{~km}^{2}$. The drainage area down to Kowalskie reservoir is $189.35 \mathrm{~km}^{2}$. The reservoir was built in 1984 . Its length is $7.1 \mathrm{~km}$ and width $0.27 \mathrm{~km}$. The depth of the reservoir varies from $1.5 \mathrm{~m}$ in the upper part to $6.5 \mathrm{~m}$ near main dam. The area of inundation in the normal condition is 203 ha and total capacity is $6.58 \times 10^{6} \mathrm{~m}^{3}$. The Kowalskie reservoir have a twostages construction. The main idea of this solution was to split the reservoir in two parts, namely the main part and the upper sedimentation zone. To achieve this goal two dams were built. The first one is the main dam located in $15+428 \mathrm{~km}$ which works in the same conditions as in the ordinary single-stage reservoir. The area of this part of the reservoir is 162.8 ha and the total capacity $5.99 \cdot 10^{6}$ $\mathrm{m}^{3}$. The second is a smaller dam located in $\mathrm{km}$ 19+888 in the upper part of the reservoir. The upper dam has a small sluice. The area of the upper part is 40.4 ha and the capacity of this part is 0.59 $10^{6} \mathrm{~m}^{3}$. The upper part of this reservoir plays a specific role. It is us a mainly for water quality protection and to collect the sediment. Kowalskie is a multi-purpose reservoir. It includes water storage for irrigation, flood protection, recreation, fisheries and to maintaining the biological flow downstream the main dam location. The Kowalskie reservoir works in annual cycle. The water surface level varies from the minimum elevation $85.00 \mathrm{~m}$ a.s.l. to maximum elevation $87.45 \mathrm{~m}$ a.s.l. Normal water level is $87.00 \mathrm{~m}$ a.s.l. The lower level $85.00 \mathrm{~m}$ a.s.1 is kept during the first part of hydrological year from November to February. In March the water are stored in reservoir. From April to September the water surface level in maintain on the normal level. Finally, the stored water are discharged in October.

\section{RESULTS}

The flows in the years 1971-2012 at the Wierzenica gauge station varied from $0.006 \mathrm{~m}^{3} \cdot \mathrm{s}^{-1}$ to $11.26 \mathrm{~m}^{3} \mathrm{~s}^{-1}$. The mean annual discharge in this pe$\operatorname{riod}$ is $0.78 \mathrm{~m}^{3} \mathrm{~s}^{-1}$. The Główna river has strongly developed naval regime. Mean runoff in spring months exceeds the mean annual runoff by $180 \%$. The average unit outflow from the basin is $3.5 \mathrm{dm}^{3} \cdot \mathrm{s}^{-1} \mathrm{~km}^{-2}$. The average annual outflow in analyzed period was $24.6 \times 10^{6} \mathrm{~m}^{3}$. The Impounded Runoff index (IR) calculated as the ratio of reservoir capacity in the normal conditions to mean annual runoff is 0.26 .

In order to assess the impact of the Kowalskie reservoir on hydrological regime of the Główna river sets of four measures are calculated for each of the 32 hydrologic parameters. These are (1) the medians (Med), (2) coefficients of dispersion $(\mathrm{CoD}),(3,4)$ ranges (Min, Max). Subsequently, values of the $25^{\text {th }}$ and $75^{\text {th }}$ percentile based on the pre-impact flows data are calculated. These values are considered the lowest and highest boundaries of the RVA target range. In the final step the alteration of hydrological regime is calculated and classified into one of three groups explained above: $\mathrm{L}$ - minimal or no alteration, $\mathrm{M}$ - moderate alteration and $\mathrm{H}-$ high alteration. The results of the RVA analysis are shown in Table 3 and Figure 2.

The results presented above indicate that the magnitude of monthly median flows in the postimpact period are lower than the pre-impact values. The largest differences between the median monthly flows are seen for periods from December to April. The mean difference is about $0.96 \mathrm{~m}^{3} \mathrm{~s}^{-1}$. The smallest differences are observed from June to September. Their average equals $0.05 \mathrm{~m}^{3} \mathrm{~s}^{-1}$. High degree of HA were observed in December, January, April and May. In these months the median flows fell within the RVA boundaries less often than expected. Most of annual median flows for December after 1984 are beyond the RVA low boundary (Figure 3a). The low degree of hy- 
Table 3. Index of hydrological alteration for data from the Wierzenica gauge station

\begin{tabular}{|c|c|c|c|c|c|c|c|c|c|c|c|c|}
\hline \multirow{2}{*}{ IHA index } & \multicolumn{4}{|c|}{ Pre dam period 1971-1983 } & \multicolumn{4}{|c|}{ Post dam period 1984-2012 } & \multicolumn{2}{|c|}{ RVA boundaries } & \multicolumn{2}{|c|}{$\mathrm{HA}$} \\
\hline & Med. & CoD & Min & Max & Med. & CoD & Min & Max & Low & High & HA value & HA class \\
\hline \multicolumn{13}{|l|}{ Group 1} \\
\hline November & 0.66 & 0.96 & 0.15 & 1.75 & 0.30 & 1.73 & 0.12 & 1.77 & 0.52 & 0.89 & -46 & M \\
\hline December & 1.14 & 0.69 & 0.28 & 2.07 & 0.33 & 1.42 & 0.13 & 2.49 & 0.95 & 1.38 & -100 & $\mathrm{H}$ \\
\hline January & 1.55 & 0.81 & 0.53 & 4.88 & 0.46 & 1.52 & 0.16 & 3.09 & 1.26 & 1.98 & -91 & $\mathrm{H}$ \\
\hline February & 1.42 & 0.79 & 0.70 & 3.03 & 0.66 & 2.32 & 0.14 & 2.98 & 1.29 & 1.82 & -63 & M \\
\hline March & 1.75 & 0.70 & 1.03 & 4.74 & 0.65 & 1.57 & 0.14 & 3.99 & 1.52 & 2.35 & -64 & M \\
\hline April & 1.82 & 0.37 & 0.78 & 2.51 & 0.76 & 1.14 & 0.07 & 2.64 & 1.48 & 1.99 & -78 & $\mathrm{H}$ \\
\hline May & 0.79 & 0.49 & 0.39 & 1.90 & 0.48 & 1.06 & 0.06 & 1.42 & 0.71 & 0.85 & -82 & $\mathrm{H}$ \\
\hline June & 0.67 & 0.76 & 0.15 & 1.20 & 0.26 & 0.94 & 0.05 & 0.76 & 0.35 & 0.78 & -18 & L \\
\hline July & 0.34 & 1.24 & 0.06 & 1.92 & 0.30 & 0.88 & 0.04 & 0.76 & 0.20 & 0.42 & 17 & L \\
\hline August & 0.26 & 2.31 & 0.05 & 3.31 & 0.24 & 0.77 & 0.04 & 1.63 & 0.15 & 0.66 & 61 & M \\
\hline September & 0.30 & 2.38 & 0.05 & 1.28 & 0.20 & 0.99 & 0.02 & 1.22 & 0.20 & 0.65 & 8 & L \\
\hline October & 0.61 & 0.92 & 0.07 & 1.12 & 0.26 & 0.87 & 0.07 & 1.32 & 0.36 & 0.76 & -46 & M \\
\hline \multicolumn{13}{|l|}{ Group 2} \\
\hline 1-day minimum & 0.21 & 0.83 & 0.05 & 0.48 & 0.11 & 0.68 & 0.01 & 0.24 & 0.14 & 0.24 & -18 & L \\
\hline 3-day minimum & 0.21 & 0.85 & 0.05 & 0.48 & 0.12 & 0.75 & 0.01 & 0.30 & 0.14 & 0.24 & -10 & L \\
\hline 7-day minimum & 0.23 & 0.80 & 0.05 & 0.49 & 0.13 & 0.64 & 0.01 & 0.36 & 0.14 & 0.25 & -19 & L \\
\hline 30-day minimum & 0.26 & 1.22 & 0.05 & 0.51 & 0.15 & 0.70 & 0.02 & 0.44 & 0.15 & 0.37 & 34 & M \\
\hline 90-day minimum & 0.33 & 1.69 & 0.06 & 0.81 & 0.21 & 0.67 & 0.04 & 0.53 & 0.16 & 0.62 & 97 & $\mathrm{H}$ \\
\hline 1-day maximum & 4.18 & 0.86 & 1.34 & 11.26 & 2.42 & 1.07 & 0.39 & 6.08 & 3.50 & 6.22 & -19 & L \\
\hline 3-day maximum & 4.18 & 0.91 & 1.34 & 10.67 & 2.31 & 1.17 & 0.39 & 5.87 & 3.28 & 6.03 & -28 & L \\
\hline 7-day maximum & 4.18 & 0.84 & 1.30 & 10.27 & 1.95 & 1.23 & 0.38 & 5.62 & 3.15 & 5.31 & -37 & M \\
\hline 30-day maximum & 3.14 & 0.77 & 1.09 & 5.82 & 1.30 & 1.25 & 0.35 & 4.12 & 2.57 & 3.75 & -64 & M \\
\hline 90-day maximum & 2.43 & 0.37 & 0.86 & 3.12 & 0.96 & 1.03 & 0.31 & 3.07 & 2.02 & 2.65 & -82 & $\mathrm{H}$ \\
\hline Base flow index & 0.17 & 0.57 & 0.07 & 0.35 & 0.23 & 0.72 & 0.05 & 0.54 & 0.14 & 0.20 & -28 & L \\
\hline \multicolumn{13}{|l|}{ Group 3} \\
\hline Date of minimum & 209 & 0.18 & 183 & 308 & 232 & 0.23 & 24 & 355 & 201 & 242 & -37 & M \\
\hline Date of maximum & 52 & 0.14 & 8 & 283 & 70 & 0.18 & 12 & 260 & 37 & 72 & -28 & L \\
\hline \multicolumn{13}{|l|}{ Group 4} \\
\hline Low pulse count & 2 & 0.75 & 0 & 6 & 5 & 1.10 & 0 & 20 & 1 & 2 & -78 & $\mathrm{H}$ \\
\hline Low pulse duration & 12 & 10.25 & 6 & 223 & 6 & 4.29 & 2 & 147 & 7 & 83 & -19 & L \\
\hline High pulse count & 5 & 0.60 & 0 & 8 & 2 & 2.50 & 0 & 10 & 4 & 6 & -72 & $\mathrm{H}$ \\
\hline High pulse duration & 8 & 1.21 & 1 & 41 & 5 & 1.71 & 1 & 63 & 7 & 10 & -82 & $\mathrm{H}$ \\
\hline \multicolumn{13}{|l|}{ Group 5} \\
\hline Rise rate & 0.10 & 0.63 & 0.01 & 0.19 & 0.04 & 0.81 & 0.02 & 0.15 & 0.09 & 0.12 & -82 & $\mathrm{H}$ \\
\hline Fall rate & -0.08 & -0.66 & -0.19 & -0.02 & -0.04 & -0.63 & -0.13 & -0.01 & -0.08 & -0.06 & -100 & $\mathrm{H}$ \\
\hline Number of reversals & 57 & 0.39 & 38 & 87 & 96 & 0.23 & 54 & 162 & 55.2 & 65.4 & -100 & $\mathrm{H}$ \\
\hline
\end{tabular}

drologic alteration is observed in June, July and October. In these month's median flows in postimpact period fell to the RVA boundaries with the same frequency like in the pre-impact period. In August median monthly flows in post impact period are characterized by a small variability. The value fell in the RVA boundaries more frequently that it is observed for the pre dam period (Figure 3b). The maintenance of flows from July to September on the same level as in the pre-im- pact period is mainly caused by water release of Kowalskie reservoir in dry season.

The differences in annual minimum flows decreases slightly in the post impact period. Significant differences are observed in the annual maximum flows between two periods, the post impact values are smaller than the pre-impact values. Subsequently, the base flow index after dam construction is slightly higher. The majority of extreme minima indicate the minimal alteration. For ex- 


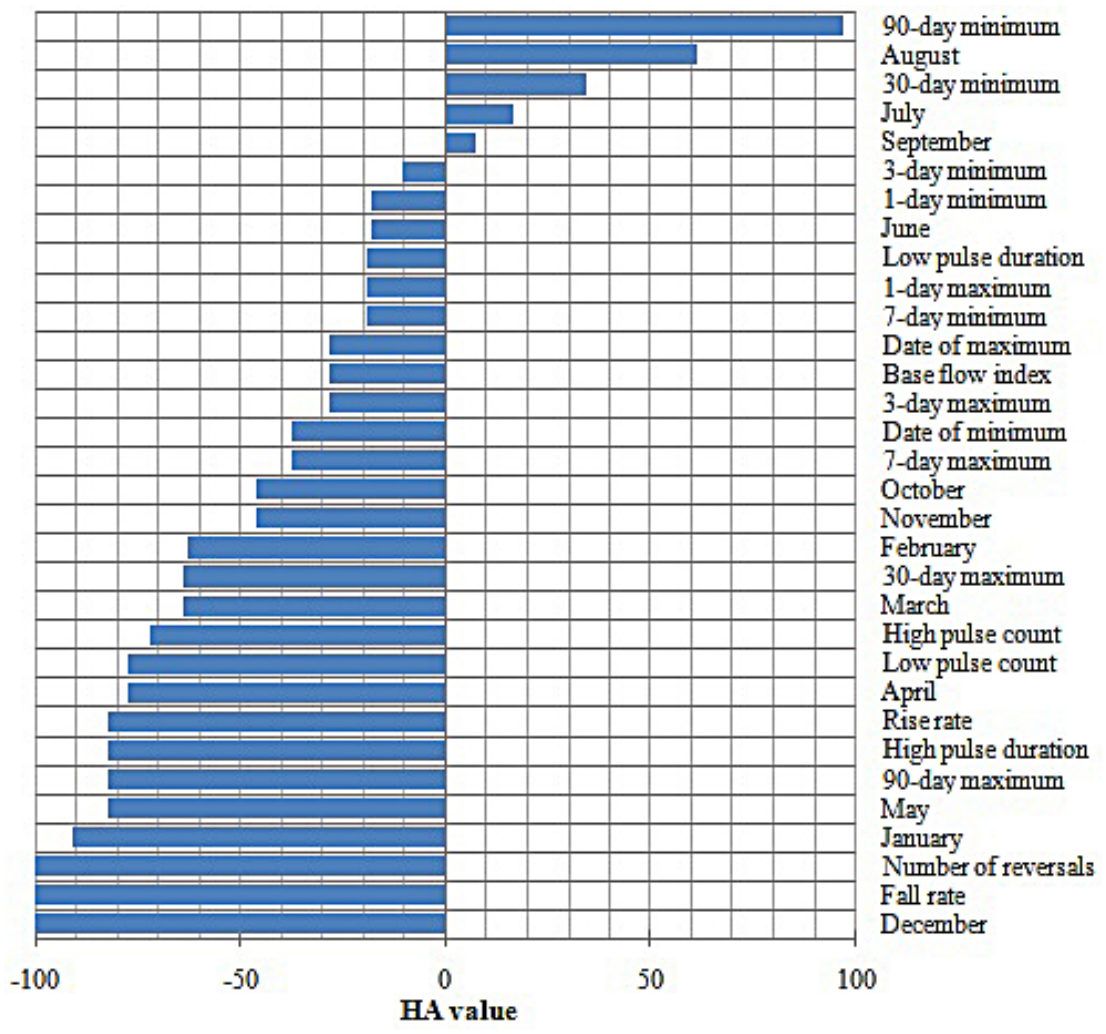

Figure 2. HA value for 32 IHA parameters

ample, the annual 1-, 3- and 7-day minimum flows observed in the Wierzenica gauge station fell less frequently within the RVA boundaries, with low alteration of $-18 \%,-10 \%$ and $-19 \%$ respectively. The 30 - and 90 day minimum flows show moderate and high alteration. These values fell more frequently to RVA boundaries. That fact suggests the buffering effect of the Kowalskie reservoir on flow variation in the Główna river. The effect of the Kowalskie reservoir operation on 90-day minimum flows is shown in Figure 4a. The alteration of base flow index is reaches minimum value and post-impact value are generaly greater than the RVA highest boundaries (Figure 4b). In contras the 90-day maximum flows are decreased after dam construction (Figure 4c). The annual 90-day maximum in the post-impact period is beyond the RVA lowest boundary. These results suggest that the Kowalskie reservoir play a major role in flood protection and enables maintaining the flow in summer season mainly the biological flow. The impact of the Kowalskie reservoir on 1- and 3-day maximum annual flows is visible on the lowest level. The maintained the high flow downstream the reservoir enable to protect the water and water related ecosystems with respect the flood protection rules (Figure 4d).

The Julian dates of 1-day of minimum and maximum in the post-impact period are later than in the pre-impact period. The differences are about 23 and 18 days, respectively. However, these values fell less frequently within the RVA boundaries. The HA value for 1-day annual minimum and maximum reached $-37 \%$ and $-28 \%$. It means that these values should be classified as moderate and low degree of alteration (Figures $5 \mathrm{a}$ and $5 \mathrm{~b}$ ).

The frequency and duration of high pulse is changed more than that of low pulse. The number of high pulses and its duration in post-impact period decreases for about 3 days. Most of annual high pulses fell below the RVA low boundary. The HA index for these parameters indicate the high alteration after dam construction. In the case of low flow pulse a little bit different results are obtained. The frequency and duration of low flow pulse is increased. The annual median value of low pulse count indicates the high alteration in the post-impact period. Almost all of the annual low pulse count fell behind the RVA high boundary with HA $-78 \%$. The durations of low pulses in the post-dam period are on the same level like before dam construction.

The annual median value of rise and fall rate is decreased in the post-impact period. The median values of this parameters are beyond the RVA low boundary. The HA value for rise and fall rate are $-82 \%$ and $-100 \%$, respectively, what indicates 


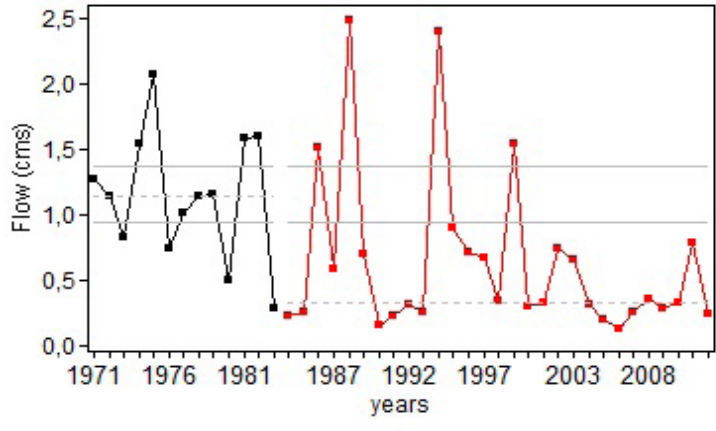

a

- Pre-Impact Flows (1971-1983) - Post-Impact Flows (1984-2012

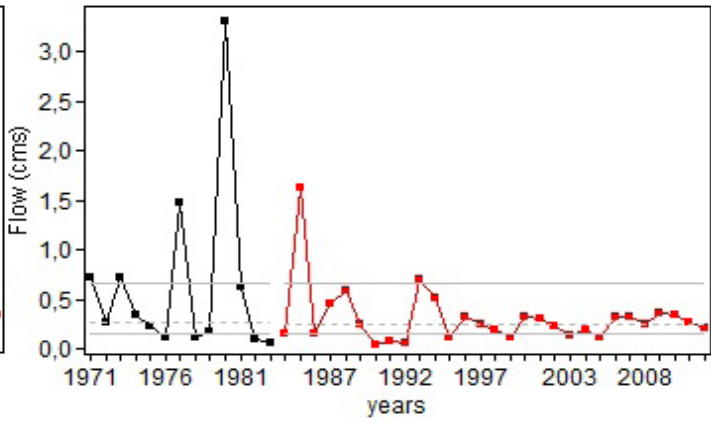

b

RVA High Boundary Median

RVA Low Boundary

Figure 3. Median monthly flows for December (a) and August (b) at the Wierzenica gauge station

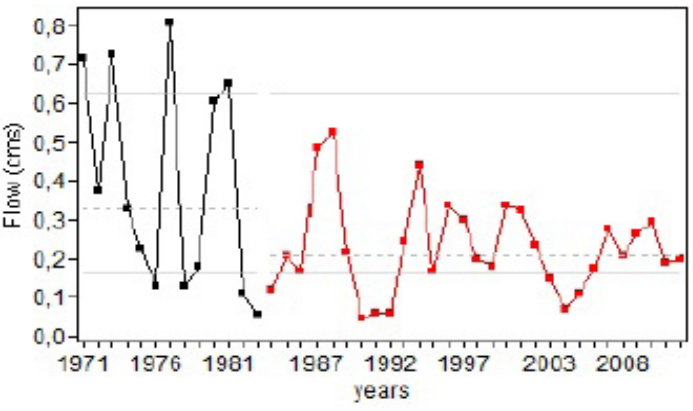

a

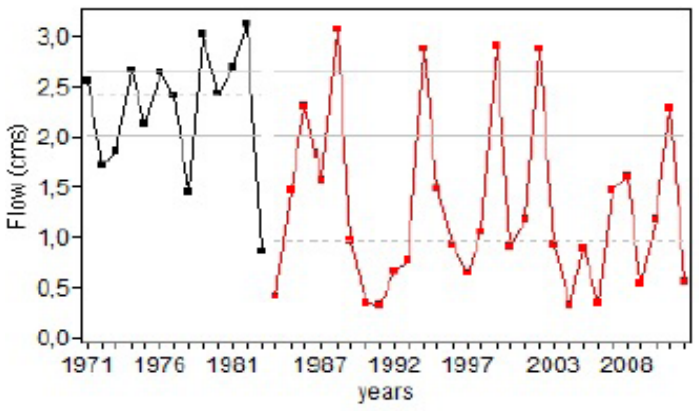

c

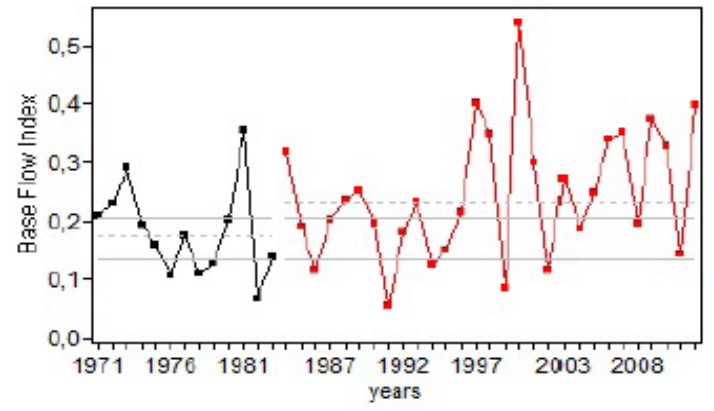

b

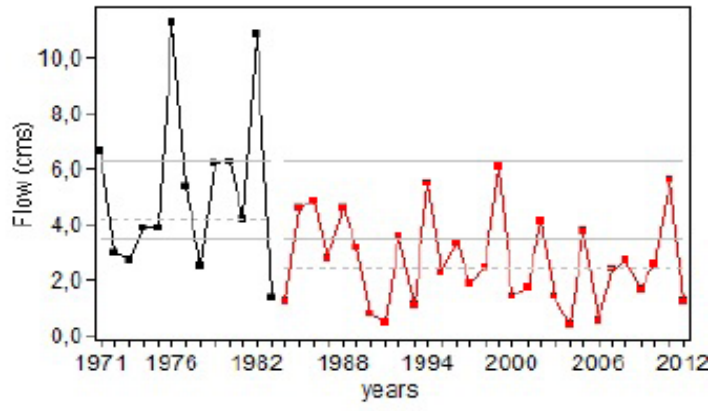

d

\begin{tabular}{ll}
- - Pre-Impact Flows (1971-1983) & RVA High Boundary \\
- Post-Impact Flows (1984-2012) & Median \\
\hline & RVA Low Boundary
\end{tabular}

Figure 4. The impact of the Kowalskie reservoir on magnitude and duration of annual extreme water conditions (a) 90-minimum flow, (b) base flow index, (c) 90-day maximum flow, (d) 1-day maximum flow

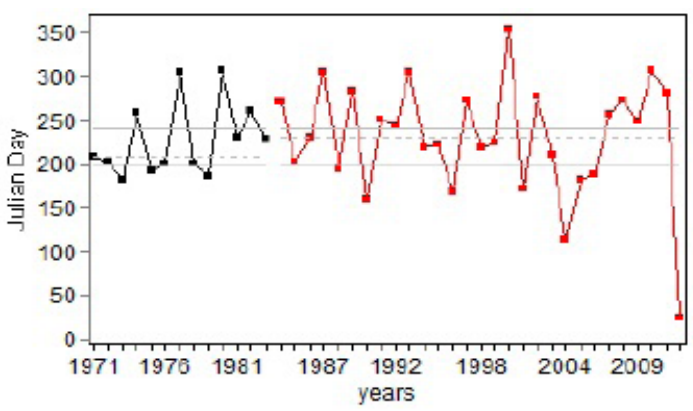

a

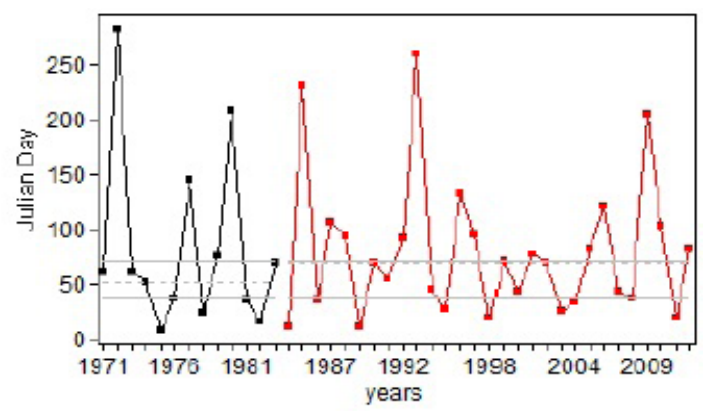

b

- Pre-Impact Flows (1971-1983)

- Post-Impact Flows (1984-2012)

RVA High Boundary Median

RVA Low Boundary

Figure 5. Timing of annual extreme water conditions (a) minimum, (b) maximum 
the high alteration. It suggests that the Kowalskie reservoir equalizes the flows downstream the main dam. On the contrary the number of reversal is increased. The median values of this parameter are behind the RVA high boundary. The HA value for number of reversal indicates a high alteration.

\section{CONCLUSIONS}

This study indicates that construction and operation of the Kowalskie reservoir may have a significant impact on hydrological regime of the Główna river. The analysis shows that:

1. The minimum, median and maximum flows in Główna river in the period of 1971-2012 is decreased. Especially, in the last 10 years we see a significant reduction of flow. This may be caused by a change in the distribution of precipitation during the year and less number of snowy winters.

2. The main changes are observed in two groups of parameters that characterized the frequency and duration of high and low pulses as well as rate and frequency of water condition change. The magnitude and duration of annual extreme water conditions are less affected.

3. The Kowalskie reservoir plays a significant role in a flood protection. The reservoir operation reduces the maximum flow in spring season. Otherwise the 1- and 3-day maxima enable to mitigate the water to river related ecosystems.

4. The reservoir operation has positive effect on minimum flows characteristic and base flow index. The changes of these values are the smallest with respect to the median and maximum flows.

5. To reduce the effect of the Kowalskie reservoir on aquatic and water related ecosystem it is essential to improve the current operation rules.

\section{Acknowledgements}

The daily hydrological data from 1984 to 2012 are provided by Institute of Meteorology and Water Management - National Research Institute. This work is a part of a PhD dissertation MSc Joanna Jaskuła "The impact of reservoirs on physicochemical and morphological state of the lowland rivers".

\section{REFERENCES}

1. Batalla R.J., Gomez C.M., Kondolf G.M. 2004. River impoundment and changes in flow regime,
Ebro River basin, northeastern Spain. Journal of Hydrology, 290, 117-136.

2. Fantin-Cruz I., Pedrollo O., Girard P., Zeilhofer P., Hamilton S.K. 2015. Effects of a diversion hydropower facility on the hydrological regime of the Correntes River, a tributary to the Pantanal floodplain, Brazil. Journal of Hydrology, 531, 810-820.

3. Guo H., Hu Q., Zhang Q., Feng S. 2012. Effects of the Three Gorges Dam on Yangtze River flow and river interaction with Poyang Lake, China: 20032008. Journal of Hydrology, 416, 19-27.

4. The Nature Conservancy 2009. Indicators of Hydrologic Alteration Version 7.1.0.10 software.

5. Magilligan F.J., Nislow K.H. 2005. Changes in hydrologic regime by dams. Geomorphology, 71(1), 61-78.

6. Matos J.P., Cohen T., Boillat J.L., Schleiss A.J., Portela M.M. 2010. Analysis of flow regime changes due to operation of large reservoirs on the Zambezi River. Environmental Hydraulics-Proceedings of the 6th International Symposium on Environmental Hydraulics, 6, 337-342.

7. Olden J.D., Poff N.L. 2003. Redundancy and the choice of hydrologic indices for characterizing streamflow regimes. River Research and Applications, 19(2), 101-121.

8. Pociask-Karteczka J. (Ed.) 2006. Basin - properties and processess. Jagiellonian University Press, 55-58 [in Polish].

9. Richter B.D., Baumgartner J.V., Braun D.P., Powell J. (1998). A spatial assessment of hydrologic alteration within a river network. Regulated Rivers: Research \& Management, 14(4), 329-340.

10. Richter B.D., Baumgartner J.V., Powell J., Braun D.P. 1996. A method for assessing hydrologic alteration within ecosystems. Conservation biology, 10(4), 1163-1174.

11. Richter B.D., Baumgartner J., Wigington R., Braun D. 1997. How much water does a river need?. Freshwater biology, 37(1), 231-249.

12. Tebakari, T., Yoshitani, J., Suvanpimol, P. 2012. Impact of large-scale reservoir operation on flow regime in the Chao Phraya River basin, Thailand. Hydrological Processes, 26(16), 2411-2420.

13. Wang Y., Wang D., Wu J. 2015. Assessing the impact of Danjiangkou reservoir on ecohydrological conditions in Hanjiang river, China. Ecological Engineering, 81, 41-52.

14. Yan Y., Yang Z., Liu Q., Sun T. 2010. Assessing effects of dam operation on flow regimes in the lower Yellow River. Procedia Environmental Sciences, 2, 507-516.

15. Yu C., Yin X.A., Yang Z. 2015. A revised range of variability approach for the comprehensive assessment of the alteration of flow regime. Ecological Engineering.

16. Zuo Q., Liang S. 2015. Effects of dams on river flow regime based on IHA/RVA. Proceedings of the International Association of Hydrological Sciences, $368,275-280$. 